\title{
Faith in science? How "micro families" viewed the Zika Virus science happen to their children in Recife/PE
}

Fé na ciência? Como as famílias viram a ciência do vírus Zika acontecer em suas crianças no Recife/PE

\section{Soraya Fleischer}

\section{(2) OpenEdition} Journals

\section{Electronic version}

URL: https://journals.openedition.org/aa/9478

DOI: $10.4000 /$ aa.9478

ISSN: 2357-738X

\section{Publisher}

Programa de Pós-Graduação em Antropologia Social (UnB)

\section{Printed version}

Number of pages: 189-207

ISSN: 0102-4302

\section{Electronic reference}

Soraya Fleischer, "Faith in science? How "micro families" viewed the Zika Virus science happen to their children in Recife/PE", Anuário Antropológico [Online], v.47 n.1 | 2022, Online since 31 January 2021, connection on 24 July 2022. URL: http://journals.openedition.org/aa/9478 ; DOI: https://doi.org/ 10.4000/aa.9478

\section{(c) (i) (9)}

Creative Commons - Attribution-NonCommercial-NoDerivatives 4.0 International - CC BY-NC-ND 4.0 https://creativecommons.org/licenses/by-nc-nd/4.0/ 
Faith in science? How families saw the science of the Zika virus happen to their children in Recife/PE Soraya Fleischer

\section{OpenEdition}

Journals

\section{Edição electrônica}

URL: http://journals.openedition.org/aa/9478

DOI: $10.4000 / a a .9478$

ISSN: 2357-738X

\section{Editora}

Programa de Pós-Graduação em Antropologia Social (UnB)

\section{Referência eletrônica}

Soraya Fleischer, «Faith in science? How families saw the science of the Zika virus happen to their children in Recife/PE», Anuário Antropológico [Online], v.47 n.1| 2022. URL: http://journals. openedition.org/aa/9478; DOI: https://doi.org/10.4000/aa.9478

\section{(c)}

Anuário Antropológico is licensed under a Creative Commons. Atribuição-SemDerivações-SemDerivados CC BY-NC-ND 


\title{
Faith in science? How families saw the science of the Zika virus happen to their children in Recife/PE
}

DOI: https://doi.org/10.4000/aa.9478

\author{
Soraya Fleischer \\ University of Brasília - Brazil \\ Professor at the Department of Anthropology, Institute of Social Sciences, University of Brasília, Brasília, \\ Brazil. PhD in Anthropology from the State University of Rio Grande do Sul (2007) and with a recent post- \\ -doctoral internship also in Anthropology at the State University of Santa Catarina (2022). Co-coordinates \\ the Anthropology and Public Health Collective (CASCA) and the podcast Mundaréu.
}

ORCID: $\odot \odot \odot \odot-\odot \odot \odot 2-7614-1382$

soraya@unb.br
The Zika virus (ZV) arrived in Brazil as a new epidemic between the years of 2015 and 2016. Its main consequence was reproductive, with the birth of more than 4,000 children with what was called the Congenital Zika Virus Syndrome (CZVS), a complex set of disabilities that requires a range of specialized care. So far, in the anthropological literature, much has been said about these disabilities, about the daily care and rights of these children and their families, but not so much has been documented about the relationship they had with science that tried to understand this new virus, this new syndrome. The article discusses why this specific population accepted the invitations coming from science and their critical reflections on this intense interaction with science. Based on a collective and ethnographic along four years of research in Recife/PE, the epicenter of the ZV epidemic, the article intends to contribute to an Anthropology of science less "internal to the laboratory", since the research subjects involved in the production of knowledge about the ZV and CZVS also helped to assess and - most importantly - construct this science.

Epidemia do vírus Zika; Recife; Antropologia da ciência.
O vírus Zika (VZ) se instalou no Brasil como uma nova epidemia entre os anos de 2015 e 2016. Sua principal consequência foi reprodutiva, com o nascimento de mais de 4.000 crianças com o que se convencionou chamar de Síndrome Congênita do Vírus Zika (SCVZ), que reúne um conjunto complexo de muitas deficiências e exige vários tipos de cuidado especializado. Até o momento, na literatura antropológica, muito foi dito sobre essas deficiências, sobre o cotidiano de cuidados e de direitos dessas crianças e suas famílias, mas nem tanto foi documentado sobre a relação que elas mantiveram com a ciência, que, por muito tempo, tentou compreender esse novo vírus, essa nova síndrome. 0 artigo apresenta razões para essas pessoas terem aceitado os convites vindos da ciência e também terem tecido reflexões mais críticas sobre esse intenso convívio com a mesma. Com base em pesquisa coletiva e etnográfica, realizada em quatro anos no Recife/PE, epicentro da epidemia do VZ, o artigo pretende contribuir com uma Antropologia da ciência menos "interna ao laboratório", já que os sujeitos de pesquisa envolvidos na produção de conhecimento sobre o VZ e a SCVZ também ajudaram a avaliar e - mais importante - a construir essa ciência.

Zika virus pandemic; Recife; Anthropology of Science. 


\section{Introduction: the virus, the syndrome, and the science ${ }^{1}$}

Zika Virus (ZV) settled in Brazil as a new epidemic between 2015 and 2016, mainly. Its central consequence was reproductive, with the birth of more than 4,000 children with what is conventionally called the Congenital Zika Virus Syndrome (CZVS). From an anthropological point of view, much has been studied and published about children and their families, but not so much has been documented on the science of ZV and CZVS. The few recent works from the Social Sciences on the science of the $\mathrm{ZV}$ tend to prioritize the scientists directly involved in this production, the names that were awarded, sooner or later, with the pioneering discoveries (Diniz 2016, Lowy 2019). In addition to national, international, and renowned scientists, there was a large group of local and unknown scientists who worked in health services and universities in the Metropolitan Region of Recife (MRR), the epidemiological epicenter of the $\mathrm{ZV}$ in that biennium. These last few appeared in this recent and hagiographic history of the so-called science with a capital "S" (Latour 2000).

But there are still other actors, such as the ZV-infected children and families who care for CZVS, which have rarely been addressed in studies on the science of the ZV. As Rabeharisoa and Callon recalled, "questions concerning relations between scientists and non-scientists, experts, and lay people - especially in the production and dissemination of knowledge - have received little attention from the empirical or theoretical viewpoints, at least until quite recently" (2003, 194). These authors suggest that Science studies, by focusing on getting to know laboratories and their scientists, end up being "rather internal to science" $(2003,193)$. When, eventually, they appeared in anthropological production, families affected by the epidemic were generally considered by the "domestic science" they produce (Diniz 2016, Barros 2021). That is, a knowledge that comes from the intimacy and intensified coexistence with these children in the space of the house and of daily care (Pols 2014).

Considering the relationship among home, clinic, and science is important because, precisely, health professionals and researchers make up a set of actors with whom these families are intensely interrelated. This is also the case for patients with rare diseases and their caregivers, as shown by Rabeharisoa and Callon $(2003,195)$ and their colleagues who have studied the involvement of patients with science (Rabeharisoa et al. 2014, Nunes et al. 2010, Moreira 2014, Moreira et al. 2014). This has been a movement since the mid-20th century. Anthropologists in France, Portugal, and England have witnessed the many exchanges of knowledge of patients, patient associations, and researchers. For example, from their ethnography with the French Association against Myopathies (AFM), Rabeharisoa and Callon noted that, in a broader context, of the 156 organizations they mapped at the turn of the century, " $34 \%$ do indeed fund research" $(2002,59)$. These were small groups that prioritized resources for science and, at the time, on average, donated $40 \%$ of their budget to research (ibid.).

The family associations, which emerged in the Metropolitan Region of Recife at the beginning of the ZV epidemic, had similar goals to patient associations in
1 I would like to thank my father, David Fleischer, for helping me with the first version of this translation; and also, Gislene Barral for the careful final revision of the translation. 
other parts of the world: "elaborate a collective identity", "support their social integration", "bring the disease before the public eye" (Rabeharisoa and Callon 2002, 58) and guarantee the survival of children with CZVS (Scott et al. 2017). Science was sought, above all, as a practice of care, to try to find answers and improvements for these children's health and quality of life. But, unlike patient organizations in those European countries, there was no participation, for example, in the design and funding of research projects or anything like "research advocacy" (Rabeharisoa et al. 2012, 8). And, in terms of resources, it was science that eventually offered opportunities and donations to children with CZVS, their families, and NGOs in Recife, not the other way around.

Although families sought out specialists to deal with their sons and daughters' specific symptoms, much more often, they were contacted by researchers (Rabeharisoa et al. 2012, 20-1). The families were found by the medical records of the health institutions they had visited. Also, through the NGOs that, in face-to-face meetings and WhatsApp groups, relayed the invitations received from scientists. Although the community associations have been hosts of the ZV science, playing an informal role in the recruitment of research subjects, the compliance and the relationship with scientists took place on an individual and family basis. So, the literature with which we will interact in this article will serve only partially, always bearing in mind that, in the MRR scenario, the relationship with science was, at first sight, "more reactive than proactive" (Rabeharisoa et al. 2012, 20) and it was more individualized than collective.

Yet, our MRR data points to another form of dialogue with science ${ }^{2}$. The interlocutors we met had a lot to say about the biomedical science they encountered in recent years. Although they were, at all times, reflecting on their direct learning from the children (the "domestic science"), they were also accumulating impressions and maturing opinions about the way in which scientists approached and related with the children ${ }^{3}$. Here, we will avoid separating the house from the clinic, the lay mother from the specialized professional, the observed object from the observing subject. The bet, to become less "internal to the laboratory" (Rabeharisoa and Callon 2003), is that these research subjects immersed themselves intensely in the research and, even if from a different perspective from that of the researchers, helped to evaluate and - more importantly - to construct that ZV science. By bringing to the debate other subjects who also produced the ZV science in Recife, we join those who question that "have been active in questioning the theories of knowledge and related 'hierarchies of evidence' that are often associated with the evidence-based medicine movement" (Moreira et al. 2014, 175). We suggest that other evidence, produced by those who saw this science being done up close is also relevant.

Here, we start from the idea that science is everyone's business, even if they are not bench scientists (like us from Anthropology), even if they are not from the university (like these mothers and their children with CZVS). This is particularly important in the Brazilian case, as science produced here is, in general, financed by taxpayers' money. Being public, science must also be accountable and explain
2 This ethnographic research was carried out over a quadrennium (2016-2019). Data draws from meetings, conversations, interviews, observations, and photographs and had the support of CNPq, PIBIC, Anthropology Department, and Fundação de Empreendimentos Científicos e Tecnológicos at the University of Brasília. We thank the dozens of families, children, and scientists who told us about their experiences with the ZV and CZVS, the team of 23 researchers from UnB, and the critical reading received from colleagues from Núcleo de Antropologia do Contemporâneo (TRANSES), coordinated by Sônia Maluf, my postdoctoral supervisor at the Anthropology Graduate Program, State University of Santa Catarina throughout 2021.

3 We will use the feminine plural because, for the most part, they were mothers, activists, researchers, students, teachers, academics - all female subjects - trying to understand and assist children with CZVS. 
what it does and why it does what it does. And different insights on science can be useful for the highlighting and improvement of its course ${ }^{4}$. In the first part of this article, we will situate the scientific scene of the ZV/CZVS in Recife, with its researchers and journalists, to then describe the types of relationships that were established with them in terms of "help", "reward" and "partnership". In the second part, three main complaints regarding the scientific practice will be presented to demonstrate how complex and delicate this scenario is, especially considering those who received science on their own bodies. With this, we will opt for greater flexibility, rather than rigidity, of an ongoing typology (Rabeharisoa and Callon 2002) on the way laypeople and experts relate to each other in the production of science.

\section{The Recife doctors}

Science soon mobilized itself to understand the number, far above the recent average, of births of microcephalic children ${ }^{5}$. After a few months, a consensus grew that the ZV was primarily responsible for microcephaly (Lowy 2019). So, during the epidemic years (2015-2016) and in the years that followed (2017-2019), science that arrived in the MRR was mostly a science of the $\mathrm{ZV}$, eventually also a science of the CZVS. Let us see how and with whom this science has arrived in that context ${ }^{6}$.

In Recife, hundreds of scientists were introduced to or directly approached the women responsible for children with the CZVS. One afternoon, in a waiting room at a rehabilitation clinic, our team joined four mothers and their children in wheelchairs. And we asked if they had already participated in surveys. All said yes, "There was too much research". One of them said that she "participated in so many research projects, signed so many terms ${ }^{7}$, that if every paper she signed was worth a [Brazilian] real, she would already be rich". We asked where this research had taken place and they explained: "in all kinds of colleges and universities". But from what we have learned, several other places served as a setting for science to take place: community associations, hospitals, physiotherapy clinics, and even at the homes of these interlocutors, for example. And, as the MRR concentrated the main services dedicated to these children, many families came from the interior of the state for the birth, then consultations, examinations, therapy sessions, and, on these occasions, were also invited by researchers. So, science did not need to hit the road and make an "active search" in the most distant municipalities from the capital as the research subjects came to their needles, portable freezers, and questionnaires.

This intense presence and this variety of spaces helped to amalgamate some actors, such as health professionals, researchers, professors, residents, interns, students, etc. Often, the same person served as a doctor in an office and carried out research at the university where she was also a professor. Clinic, science, and teaching are common attributions of a professional from the health areas. Therefore, a meeting between a woman, her child and this professional could have different purposes, such as carrying out an examination to define a diagnosis;
4 We refer to science in the singular, without the intention of essentializing or creating a single idea of scientific enterprise, but as a generalized portrait of research initiatives from various areas that arrived in the region. During the biennium of the epidemic (2015-2016), on the Plataforma Brasil, we found 99 research projects carried out by local researchers in the MRR (Simas 2020).

5 Microcephaly occurs when, at birth, the cranial diameter is less than $32 \mathrm{~cm}$. In the case of $\mathrm{ZV}$, it is one of the symptoms of CZVS. Families used the adjective "micro" in a general way to identify the child, the specialists, and the services that attended to them, as well (for further details, see the "Introduction" by Fleischer and Lima, 2020).

6 The fact science has prioritized ZV was a problem for the families, as some did not agree that microcephaly was caused by a virus (Fleischer, forthcoming). In addition, the majority thought that the syndrome should be the priority of research and not a mosquito, a microorganism, or vertical transmission.

7 Free and Informed Consent Term (TCLE, in Portuguese).

8 This waiting room was described in the field diary of Aissa Simas, 2018. We will only refer to excerpts from other researchers on the team, while the remaining records were produced by me. From the seven visits made to the MRR, we have written 1,800 pages of field diaries that we agreed, in an edited version, could be shared within the research team. 
clinical follow-up; collecting blood samples for a research project. If, in the health area, having multiple institutional filiations is common, it seems that the urgency of the epidemic accentuated this amalgamation between professional profiles. For example, in that same waiting room described above, when asked about the difference between "doctor" and "scientist", one of the mothers explained: "At the beginning of the outbreak, mothers were desperate, we didn't know what was going on or what to do. Then, for each doctor, three researchers came along, and they didn't give any information, they didn't say what they were doing. So, mothers could not differentiate one from the other".

This mother also explained that, sometimes, there was no invitation to participate in a survey. Data, numbers, and measurements were derived from medical records and exams, which were later included in the broader sample being constructed by the researcher. But, in general, our interlocutors reported that a more formal invitation was made, creating a different framework from a consultation, professional credentials were presented, informed consents were signed. Despite the spaces, roles, and formats of the relationship, with more or less formality, there were so many occasions on which the scientific gaze was directed at these children that, sometimes, when we returned to Recife, one or another woman did not recognize us, did not remember our research specifically. We were also part of the amalgam, Anthropology stuck to Medicine, field notebooks looked like clipboards and forms, questions could be from a qualitative study or news coverage.

So, to translate this amalgam, we suggest a diffuse category, but distinct enough to capture the aura of prestige and exoticism that surrounds it. "Doctor" could be, at the same time, a medical doctor, a bench scientist, the head of an outpatient clinic, a field researcher, and/or a university professor. In this sense, the doctor was linked to the world of schooling, titles, specialization. But also, in another complementary sense, the doctor could be, as they called locally, a "top cat", an authentic representative of the Recife and Pernambuco elite, who showed off the gold of her hair and jewelry, the high heels of her stilettos, the long silicone nails, the bikini line of those who were at penthouses, clubs or the beach.

Another group of professionals, journalists, also resembled researchers. Not exactly because of the unfolding of their craft, but because of curiosity and the methodology they adopted. In that same waiting room, we took the opportunity to ask if mothers saw a difference between a reporter and a researcher and, in quick unison, they said: "There is no difference". There were always terms to sign, either the consent form or the consent of image use. An "interview" could be given to a reporter or a researcher. "It makes a difference because, for you [and here, anthropologists were included], it is for a study and for them it is for the media, but everyone asks the same questions: if it was Zika, why was it, what happened, how are the services treating the kid", one of the women explained to us. Another one, sitting next to her, added wryly, "They both ask the same questions. It makes you want to turn on a tape recorder and record everything and then give it to them, so you won't have to answer it all over again”. And they all burst out laughing with this solution. We even learned of some local research teams that perfectly under- 
stood this criticism and tried to converge instruments and databases to avoid the exhaustion of interlocutors.

But there were also certain differences. Another woman told us, valuing the immediate visibility of the media, "My daughter is famous, she has already done photoshoots for two magazines, one American and one French. She appeared on billboards and everything, she was even recognized on the street by a gringo". Cintia, as we will call another woman and with whom we had intense contact, explained, more enthusiastic with science than with journalism: "The biggest difference between a journalist and a researcher is continuity. The journalist has a topic that she needs to cover for an article. So she goes, asks about it all, and leaves. The relationship with researchers is different, it has a long-term follow-up. I am even friends with some researchers".

In recent years, these women have had an intensified contact with science, an unusual experience for most of us. This experience is valuable, both as an internal look at science (because they became research subjects) and an external look at science (because they did not become researchers). They have a lot to say to science and its scientists, as well as to an Anthropology of science. In this sense, we will try to understand what they have said, on behalf of their sons and daughters, about the science of the ZV and the CZVS, but not from the "domestic science" perspective (Diniz 2016, Pols 2014), nor as collective activism of patients and caregivers (Rabeharisoa and Callon 2002, 2003; Rabeharisoa et al. 2012), as has been more common so far. From another perspective, considering them as research subjects and guardians of research subjects, in the next section, we will show some of the reasons for valuing and ways of approaching science. Then, we will detail some of the main ways in which this coexistence took place. And, finally, we will discuss why the value of science is, little by little, destabilizing for these families affected by the ZV epidemic.

\section{Faith in science}

Families understood that the "small head" was not just a novelty for them, but also that several other actors, the doctors in particular, wanted to understand what was happening. And they were willing to introduce their sons and daughters, to describe their daily behavior, to answer questions, and, above all, to allow their little bodies to be examined on the surface and from the inside. The raw material and the answers came from children and their caregivers, while the questions and conclusions came from the scientists and journalists. Science was raised to the position of studying, understanding, and explaining the world. For many of these families, science was already and remained an important, respected, and expected practice. It occupied, therefore, a positive place, but an alien place, produced by other people (who did not experience the ZV and CZVS closely), while based on these people (who experienced it all very closely). Because of this "great divide" (Latour 2000, 377) between researchers and research subjects, it was necessary for the latter to delegate to the former the attribution of being studied. Our interlocutors agreed with this distribution of work, within the framework of a
9 Thais Souza's field diary, 2017. 
"delegation model", in which "the patients, acknowledging their ignorance, leave it to the scientists and specialists to choose the research lines to be given priority and supported, and to handle the production and distribution of theoretical and practical knowledge" (Rabeharisoa and Callon 2002, 60).

Scientists were seen as those who leave the comfort of their laboratories and go see the world, to describe "reality". Several mothers understood that doctors would be committed to looking at things seriously, neutrally, precisely. For Camille, one of the micro mothers we visited many times, science opposes what circulates through other channels as social media: "We cannot believe everything that comes up on Facebook, everything that is posted, everything that is said on WhatsApp. You must get off the phone, log off Facebook, and come see the people, come talk to them directly. You really need to see the reality". This is how she interpreted our trip from Brasília to Recife, or what other people did, such as reporters who went all the way over to her house for an interview, or as a researcher who left the university office to look at her son on the stretcher, etc. They believed in science for its instigation, curiosity, and, consequently, the production of truth. Camille and other caregivers held science - and other professions that relied on empirical scrutiny - in high regard.

Brochures and manuals, videos on the internet, and lectures were the formats through which doctors expressed their knowledge about ZV. In 2018, we attended a seminar on rare diseases promoted by a private college. Cintia accommodated herself next to us, and, with her daughter in her arms, she listened attentively to the lecture of a famous local neurologist, who was also her youngest's medical doctor. The following weekend we went to visit the family and, walking down their street, we saw a boy frantically pedaling a bicycle, carrying another one on the pillion. The rider was wearing a motorcycle helmet, but a wide smile could be glimpsed, both friends having a lot of fun with the speed. Cintia commented, referring to the pilot, "that one has microcephaly". We asked if this was the kind of revelry she expected for her daughter. In her answer, the events from the last few days were intertwined:

Yes, it is. But did you see that lecture by the doctor? The big problem for our children is not microcephaly, it's not the small head, but the calcifications. That's what makes the head not work very well, it's not its small size. And the doctor said (and I've seen her talk about it in other lectures) that no one knows how much these calcifications will impact the child in the future. How much my daughter will be able to develop.

Cintia was, no doubt, the mother with the largest enthusiasm for science. Another day, in her daughter's therapy, we asked her how her relationship with science and justice was since these families often had to judicialize discriminatory practices and claims for medication, surgeries, etc. "I certainly have more faith in science. Justice is that way, you know, we can't count on it, we can't trust it. There are already a lot of politicians within the justice system”. And we provoked her: 
"But do you continue trusting science even without receiving its results?". "I do, of course," she said with a giggle, "I have faith that I will still get the results. I really believe that something will show up for my daughter".

Visiting another mother, Mariana, we commented that Mateus, her child, was very calm, he was settled and peaceful in her lap, listening to our conversation. She told us:

It wasn't always like this. It's only now that he's calmer. At first, he cried a lot, a lot. There was one night he cried from midnight to $5 \mathrm{am}$. I slept for half an hour, and he started crying again. All the micro babies present a non-stop cry, convulsions, now they are presenting bronchoaspiration and starting to use a feeding tube. But they are making the characteristics of the syndrome, you know.

When a family made their child available to participate in research, they imagined that the "characteristics of the syndrome" would be listed, described, explained starting from that case and generalizing them to all other cases with the same diagnosis. So, identifying the common characteristics was important to move from microcephaly to what is conventionally called "Zika Virus Congenital Syndrome", where the small head became just one of the symptoms. In this sense, Mariana and her colleagues hoped that "making the characteristics" of the syndrome would offer precise care for crying, convulsions, dysphagia, and bronchoaspiration that often affected this young population.

Rabeharisoa and Callon, in their study of the French Association against Myopathies (AFM), noted "how patients were able to construct their individual and collective identities owing to the association's intense engagement in scientific and technological research activities - an engagement that enabled them to change their ontological status" $(2007,231)$. This meant, in practice, leaving the spot where these patients were placed for so long - "freaks of nature" - to the spot of human beings with disabilities explained by a "genetic flaw". And it was with the relationship with science, which described the myopathies, that this "ontological change" was made possible (ibid.).

Micro children in Recife, especially at the beginning of their lives, were also dehumanized, were called "ET", "monster" or "child of the mosquito" around the neighborhoods, streets, and buses of the city. These families, upon receiving visits from doctors, having the stories and photographs of their children illustrating scientific articles, widely circulated newspapers or even billboards, were navigating through other understandings about microcephaly. These children, with their syndromic characteristics described, became part of a research project, became an interest to science, and even became "famous", as that mother recalled paragraphs above. It seems that science, on the one hand, has contributed to bringing these children back to the limits of humanity, and a human valued for the possibility, among many, of contributing to the densification of knowledge about humanity in their contact with the ZV. On the other hand, science has "socialized patients" and 
"they become stakeholders in scientific, clinical, medical, and social networks", taking them "from a situation of exclusion to one of inclusion" (Rabeharisoa and Callon 2007, 240).

Getting to know these children better - "seeing reality", "making the characteristics", "speaking in lectures", and "making something appear" - are all information that the families hoped to receive back from science. Mariana told us during another of our visits: "Since your research is going to reach the government, I think they have to give us more help. The medication is very difficult to get. Mateus' medication is cheap, and I can afford it. But there are supplements, there is a certain milk that costs $\mathrm{R} \$ 100$ a container, can you imagine that?”. Afterwards, we accompanied her in a long interview she gave to an international human rights NGO. On the way home, she explained that, even if that conversation with the foreign journalist did not immediately or directly serve Mateus, "it is always good to be able to help other people, explain the situation of the babies I know, contribute to the government so it can improve its performance".

Especially in the beginning of our contact with these families, this active stance in responding to invitations from science and the media became very clear. Families wanted, above all, to understand the children better and they really trusted that the educated and trained people would have the necessary knowledge, resources, infrastructure, and networks to advance and expand all this understanding on the ZV and the CZVS. It was the desire to know and the faith that science would produce this knowledge that motivated many of these families to authorize the participation of their sons and daughters in research. Knowing more would allow these families, on a local scale, to be able to take better care of their children and, on a broader scale, the government, as Mariana suggested, would "improve its performance" with CZVS children. Science and media were understood as a source of information and mediation between the citizen and the State.

\section{Help, reward, and partnership}

The interlocutors soon understood that the doctors, although with the authority to research and voice conclusions, needed to have access to the children, to their symptoms. So, the children became, concretely, the empirical corpus of ZV science, and, therefore, the families said that these children were "helping" science and the media. Thus, they were also actors in this broad scenario, acting as co-producers of these scientific enterprises. Cintia, for example, told us that journalists almost always gave her something in return, as, for example, money, formula milk, diapers. She accepted this but did not charge in advance for an interview like she noticed other people do. And she explained to us, "they are not buying me, I'm helping them". And she added, "there are mothers who say, 'Oh, why am I doing an interview? I'm not getting anything out of it'. But yes, she gets something, yes, she does. She gets a voice" ${ }^{10}$. Then she recalled a time she 10 Aissa Simas' field diary, contributed to a television program and the next day she received a call from a rehabilitation center offering a place for her daughter. Andreia, another very close interlocutor, explained how she saw her scientific participation, "they come, they 
want to know about our work, what we do with our children. We receive them, we answer their questions, thinking we can help other mothers not to lose the light". There was self-interest, they wanted to transmit hope to other mothers, and they also made a broader investment by integrating research and contributing to the visibility of the epidemic, the $\mathrm{ZV}$, and the CZVS. When helping, there was certain altruism in furthering individual learning, whether for other mothers or for authorities.

Media professionals used to pay for these aids. A fee was offered for photographs, videos, testimonials. Bela, for example, told us that she had agreed, a few months before, to travel with her son to another region and participate in a city hall campaign against the Aedes aegypti mosquito, and received $\mathrm{R} \$ 2,000$ in exchange. Appearing on TV news or on billboards could mobilize food donation campaigns for the micro community. A US research project, which planned to build data from a five-year cohort with these children, offered a monthly food basket to each participating family, Bela and Cintia were part of this project. Another woman told us that she received a donation of $\mathrm{R} \$ 1,000$ from the research fund of a foreign scientist who came to Recife. Bus tickets and meals to spend the day during a blood draw were already basic requirements, no negotiation necessary. These offerings were referred to, by these women, as "rewards", and some interlocutors, pressured by their partners and relatives, decided that, over time, they would only leave their houses to "help" if the "reward" was clearly guaranteed at the beginning of the contact with the journalist or the researcher.

We understand that the rewards came in exchange for individual help, as Cintia, Bela, and Andreia described in the paragraphs above. When collective, they were called "partnerships". And, in the relationship with science, as families began to understand its timing, with results promised only in the long term, partnership became necessary. Mothers greatly desired appointments with medical specialists, which were rare in the city. The consultation could be the gateway to high-cost exams, free drug samples, therapies and restorative surgeries, assistive technologies (eyeglasses, wheelchairs, orthotics, etc.). These were items that were rarely offered by the public health system nor covered by private health insurance. Ana Caroline, an important local leader, commented at an event held by a local university and aimed at municipal managers: " $50 \%$ of our children do not have treatment. We almost go crazy trying to establish partnerships with the university. We got a house to settle our organization, we intend to set up a rehabilitation center there, but it is difficult" ${ }^{11}$. She had been noticing that, in 2017, many therapy slots were closing for children with severe neurological disabilities such as those with CZVS. A partnership with the university could happen, for example, by offering the child's biological material in exchange for follow-up consultations or rehab therapies. At that same event, another leader, Fernanda, stood up, took the hand of the president of another association of rare patients who was sitting by her side and said: "We need to walk like this, hand in hand, with scholars, with the State, with everyone. These women live completely on the fringes of society, no one has ever looked at them. So, I'm very happy, despite everything, to be dis-
11 Raquel Lustosa's field diary, 2017. 
cussing it here with you today". ${ }^{12}$

The child with the SCZV had become a valuable subject to ZV science. Recognizing the potential of this empirical corpus, families tried to take advantage of the research projects, knowing that they took place within health and teaching institutions, both of which were difficult to access. So, scientific proposals came along with clinical opportunities (Castro 2020), within public and private institutions. These opportunities were also noticed by the NGO leaders, such as Ana Caroline and Fernanda, who proposed inter-institutional arrangements so that more families could be served, moving from individual help to a collective partnership. And they bet that the biological material would feed a relationship to be continued for a longer time. They had learned about the rhythm of science, which depended on several questionnaires, many consultations, successive collections, and follow-ups. "Walking hand in hand", "summing up" and "making partnerships": these were the strategies that families and their representatives envisioned with science, universities, and their doctors.

From these three categories - help, reward, and partnership - mothers developed an ethical etiquette for their children's participation in research. Interestingly, all these terms suggested a very active participation, communicated the way these families understood the demands from science, and deliberately, positioned themselves in front of all of it. As Andreia summarized well, "it has to be good for both sides". Based on the help offered by the children and their families, Andreia's conclusion seems to be the native ethical assumption for any development, be it reward or partnership.

However, Bela noted fewer journalists and scientists in recent years. She explained that families had been receiving lesser invitations and that rewards had been dwindling. "Now we can only hope that something will change. But sometimes, you know, nothing changes at all". The change could be a public policy, a new social benefit, a vaccine against ZV, a cure for CZVS, or, as she suggested, none of that. But Bela knew, as did Cintia, Camille, Mariana, Andreia, and other mothers mentioned here, that although science or the media had the ability to influence results and decisions, changes could take much longer than the duration of a diaper donation campaign or even the lifetime of that child, for example. And if doctors were making fewer invitations to CZVS families, the making and timing of science were also less interesting to these families. Next, we will discuss a gradual loss of faith in science that we began to observe on subsequent visits to Recife.

\section{Three complaints about science}

We continue to follow Bela's ideas. One afternoon, while we were waiting for her son's consultation, Bela told us that the day before she had participated in yet another meeting of a research project with an international organization. In those meetings, among doctors and journalists of all kinds, she represented the association of mothers that she was a member of. We asked what her participation was like:

12 Yasmin Safatle's field diary, 2017. 
This is a world I dreamed of being in. I never thought that I could be like this, in the middle of so many authorities, nor that I could speak. I wanted to, but I didn't imagine that I could be such an important person. Important, I mean, with status, with audience, you know. I didn't know that I would be important for who I really am, for what I live every day. It's also very nice to be with people who have more experience than I do.

We amended, "but with your child, you have more experience than they do". She flashed a smile and quickly agreed: "'that's right, you're right. It's really an exchange. I tell them about my experience, they talk about theirs". At the end of the conversation, we asked what kind of results she expected in this exchange with this United Nations organization and the doctors of the hospital where this research group met. To our surprise, she said, skeptically: "I do not have much hope that they will make any changes, their intention is to improve, to create a network to help children, but on paper SUS [Sistema Único de Saúde/National Unified Health System] is beautiful, in practice, it is not as much"13. So, attending these spaces, being close to authorities, and, at the same time, having their own experience with their child's CZVS recognized could all be opportunities to raise their status, their image among the association's members, even their self-esteem. However, "feeling important" was perhaps a more individual sentiment than scientific results actually being incorporated in SUS, the health system ordinarily used by the community Bela represented.

But SUS would be the final point of incorporation of technologies generated by science. We need to go back in time a little and add a few more layers to this relationship between families and doctors. Although they have met many kinds of researchers, caring doctors, reporters really interested in their stories, or even this group in which Bela participated, the relationship with science raised some noise. We noticed three major complaints that refer to practices that started before the child was born and continued afterwards, during scientific protocols until more recently. Years and years of research on the $\mathrm{ZV}$ and disrespect, violence, alienation, and subalternization were still reported where science took place. Due to the intense therapeutical itineraries, they undertook in name of their children, these mothers had become specialists in the SUS (Fleischer 2020b). Now, we suggest that they were also becoming experts on the science of $\mathrm{ZV}$ that was produced from the bodies and stories of their children. They were gaining experience about the scientific culture of $\mathrm{ZV}$ and positioning themselves more critically in relation to it. Let's move on to the complaints.

The first complaint recalls the reproductive moment. During pregnancy, they heard from gynecologists; after delivery, they heard from obstetricians; and, throughout the puerperium, pediatricians and neurologists made very categorical prognoses about the child. Imagining an "expiration date", as a micro grandmother called it, these professionals said that the child "would not survive"; if he or she eventually survived, he or she would "vegetate" inert on a bed; if they vegetated, "they would not last long”. Most children defied all these diagnoses and continued to live and grow. 
Categorical assertions, divergences between opinions, and iatrogenic practices contributed to create an atmosphere of distrust on biomedicine from families. As they learned about CZVS, they were able to assess the professionals, choose whom to relate to, and learn from all these therapeutic itineraries.

The second complaint refers to the diagnosis, or rather, the lack of it. The first generation of women infected with ZV rarely had a gestational ultrasound exam, since, on the one hand, this exam is not part of the public prenatal protocol and, on the other hand, there was no suspicion of an ongoing epidemic. But after delivery, there were dozens of tests performed, not always accompanied by explanations about the reason, the procedure, the date of the result. The second generation of women, infected in the midst of a declared epidemic, experienced this profusion of tests during and after pregnancy. Still, it was common to hear from them, "nobody explained anything to me in the hospital". In a waiting room with a dozen micro mothers, Julia recalled that in the beginning, at the time of her daughter's birth, it had been very difficult, "We didn't understand anything that was happening. We went to consultations, the doctors talked and talked, and we didn't understand those words, all those explanations. They spoke too fast; they didn't explain what they meant. And we didn't understand". "We would listen in the offices and return home without knowing what they had said, right?", reinforced Lucinha, sitting next to Julia. Lucinha was the interlocutor who had invited us to follow her activities that day and, in that same room, was also waiting for her son's routine medical appointment.

In general, they did not feel comfortable communicating their doubts, asking for a slower information pace, checking words and terms. And the next phrase we heard over and over again was, "and of course, I went home and started searching around on the internet”. Yet another expert, Dr. Google, helped them find photographs, videos, testimonials, reports, scientific articles on microcephaly, then on $\mathrm{ZV}$, and later on CZVS. And Cintia, who has become a vibrant spokesperson for science, took advantage of the internet to assess whether she would do the procedures suggested by the doctors, if she would accept the invitations received from the scientists: "The doctors talked about an exam, they said a word there and I would go home and search for it on the internet, to see what it was, to check if they could do that on my daughter". Besides the internet, other sources of information also helped. When we asked if the obstetrician had explained what microcephaly was, Irene shook her head, "She explained nothing. I did not know anything. I thought it was just happening to me. Then my [older] daughter saw it on television and called me to see it too. That's when I understand that it was an epidemic, that it wasn't just me". ${ }^{14}$

Still, the lack of explanations and a definite diagnosis left these women feeling lonely until they started meeting each other in waiting rooms (similar to the ones we described here), adding each other on messaging apps and exchanging information and experience (Lustosa 2020). They were strengthened with knowledge, including information on the different doctors, hospitals, and the more attentive, didactic, and relevant research projects for their daughters and sons to join in. In
14 Thais Souza's field diary, 2017. 
this sense, Julia, mentioned above, concluded, "today, we have much more information, much more information". She repeated this word several times: "We didn't know where to get more information, where to go, whom to talk to. But today, we know much more". From inert nouns, "no", "not" and "nothing", they switched to action verbs, "to go", "to speak", "to obtain”, "to know”. They were also, in their own way, doing science: searching, researching, studying, getting information.

The third complaint had been made more recently and was a consequence of years of dialogue with science: not getting the results back. Camille recounted, resigned:

We are in a research project at [a philanthropic institution] and at [a pediatric referral hospital]. But they never gave me the results, I didn't get them back. I've requested them several times, but I gave up asking. I've even said, "I'm not even going to ask again, Doc, it's not going to work, right?". The doctor only showed it to me on her computer screen, that's the only way I could see it. On her computer, that's when I first saw the affected part of my son's brain. They took pictures of him to put in the study and told me they would return them to me later. But they never did.

For mothers like Camille, the results could be an MRI of the brain, an X-ray of the hand, or the child's blood count. All this could expand her understanding of the child's situation and then be included in the paper folder she carried around the city full of documents about her son's syndrome. "Result", therefore, is another expression that is also polysemic and amalgamated.

And a highly valued expression. Most families never received a single result back and did not have the courage to ask for it, much less insist or mock the doctor, as Camille did. Some mothers only knew it "by word of mouth", with information offered by the health professional when crossing the corridor or inside the office. Others, like Camille, could see it on the computer or the cell phone screen. Very rarely, they received results as a PDF document sent by an app. Almost no one received a paper printout from a staff member or got it sent by mail, for example. Results are understood more broadly because they could have many more purposes than those initially foreseen by researchers. They could provide access to more specialists, individual rights, and social benefits. ${ }^{15}$ And even get access to another research. Some ZV projects required, as a condition to participate, the report attesting to the CZVS or, as the mothers told us, the report linking microcephaly to the virus.

In the few cases of returned results, misplace of exams was also reported. And, thus, science, whether in the figure of the doctor, machines, or papers, looked more and more exogenous and distant, cold, and uncompromised. On the other hand, we also met mothers who were very enthusiastic about research, such as Cintia, who credited the government for the absence and exchange of results. She did not blame the researchers, but their superiors who might want to hide evidence that ZV existed, that CZVS was one of its consequences and, thus, spare
15 Free transport passes, an apartment in the "Minha Casa Minha Vida" public housing project, a special education slot in school, continuous cash benefit, or the lifetime pension were rights only guaranteed with the presentation of a dossier on the child. And results issued by doctors, in a clinical or scientific situation, were a central piece of this dossier. 
the State of guaranteeing any compensation to the victims of the epidemics. In this same sense, a woman explained to us that, "by deliberation of the public prosecutors, exams were not returned so that families could not pursue their rights".

These are not frivolous, pointless, nor far from scientific complaints. They communicate an uneven relationship between these families and science, but also an ideal image of science: if these families helped so much, why weren't they helped back in the form of rewards, partnerships, diagnoses, and results? Some women, with more voice, like Cintia, or with more humor, like Camille, managed to talk about their expectations and dissatisfaction with research projects, demanded results from the scientists, suggested other ways of working together, and even started to select more actively which scientific protocols to join. Others chose to simply walk away, lost faith in science. They could no longer sustain, as Bela suggested, "the hope that they [the doctors] will make any change".

\section{Final considerations: When families anticipate and invert their rela- tionship with science}

In caring for a child with a new virus, a complex syndrome, and a set of disabilities, hope was shaken many times, subtly or drastically, at home or around the city. It was also reconstructed many times, with shreds of information, with information from a lecture, an exam displayed on the computer screen (Fleischer 2020a). Science was seductive because it invited everyone to imagine other possibilities. Therefore, for many of the interlocutors, such as Cintia, Camille, and Mariana, science was a source of nourishment for many years. Although a significant source, it was not the only one, as Bela, Julia, Lucinha, and Irene gradually realized.

This nutrition indicates the first of the three most common types of relationship with biomedical science, according to Rabeharisoa and Callon (2002). The "auxiliary" type, where there is "a strict division of roles and missions" between researchers and research subjects (Rabeharisoa et al. 2012, 20). In this type of relationship, patients and caregivers are expected by professionals "to be cooperative so that his or her treatment [and clinical research] can be carried out under the most technically favourable conditions" (Rabeharisoa and Callon 2002, 60). Here, the actions of patients and their caregivers should be "an extension of what the doctor does" (ibid.).

The intensity with which ZV science arrived in Recife was invasive, repetitive, boring, but it gave access to a large group of doctors. Even with complaints, science and scientists remained valued and that is why there was an effort to find professionals with whom help, rewards, and partnerships could be exchanged satisfactorily, and a relationship could be established between parties. In this case, the researcher would feel more embarrassed to offer opinions that were too categorical and not very detailed; the family would feel less embarrassed to ask questions to sort out information; and if they didn't, the results could be requested more routinely, as Camille had been attempting to do.

In other words, if "it gives full rein to the wishes and projects of the professionals" (Rabeharisoa and Callon 2002, 61), it becomes unsustainable, as in the merely "auxiliary" type of relationship (ibid.). And greater selectivity about the scientists 
and their research proposals was important so that families were not completely "stripped of their influence". Then, they could move towards the second type of relationship with science, which these authors also call "partnership" (ibid.). If we did not notice participation in the initial design of research on ZV or CZVS, at least the attitude of families in relation to science was changing. More and more, the experience of families, in the sense of knowing "what it means to live with the disease (...), dictated by their intimacy with the disease" (ibid., 62), was guaranteeing them more legitimacy and authorizing them to pair up with doctors. We noticed practices such as: offering details based on "domestic science" so that "the characteristics" of CZVS could be mapped; comparing and complementing information during meetings in waiting or in consultation rooms; prioritizing those offices with an atmosphere of mutual learning between families and specialists; demanding results so that cooperation could continue in progress (Rabeharisoa and Callon 2003, 195).

Maturing opinions about science and scientists, in the form of the three complaints described, was also a way of actively participating in this scientific scenario. These caregivers were observing, evaluating, reacting to invitations, protocols, needles. And, in the face of frustrations, misunderstandings, and disagreements, instead of leaving the scene, they continued to mark their presence, demanding good scientific care for their children. They were designing better ethical conditions for ZV science based on the experience of those who lived directly with the CZVS. From our point of view, it is stimulating to watch research subjects suggesting improvements to researchers, expanding the ways science is produced. But this more critical stance did not fully illustrate the third type of relationship, the "opposition" to science, where "patients reject any defining of their state by the scientific and medical community" (Rabeharisoa and Callon 2003, 195). Still interested in maintaining some relationship with science, these micro mothers would be foreshadowing "new relationships between science and society, between those who produce knowledge and those who are meant to benefit from it" (Rabeharisoa and Callon 2002, 63). If, at first, these families were only invited by the scientists to integrate their research projects ("auxiliary"), more recently, the former already perceived themselves as more active interlocutors ("partners" and, very occasionally, "opponents") than the latter perhaps imagined.

So, instead of waiting for the results to arrive from scientists alone, we noticed an anticipation and an inversion. By carefully observing the production of science, by reporting on their experiences within this production, and by communicating their disagreements with these experiments, the families were already anticipating results to the scientists. Families were becoming a sort of scientists who studied scientists, inverting the roles of those who ask and those who answer. Women like Cintia, Mariana, and Camille not only helped science with the biological material of their sons and daughters but also suggested that science carries out its practices in a more careful and equitable way ("hand in hand"). This could be an unexpected result for researchers if they were still accommodated in a relationship with unidirectional enunciation, that is, from inside the university 
to the outside world, accustomed to being the subjects who look at and analyze objects. But we do not take the typology proposed as fixed because it does not exclude the moments when micro families oscillated between mere assistance ("auxiliary"), the most common relationship, and certain hopelessness with science ("opposition"), a more recent critical tinge to the relationship. And yet, as the leaders Ana Caroline and Fernanda showed, partnerships depended on many collective efforts carried out from all sides so that the "delegation model" and the "great divider" between "specialized know-how and lay experience" (Rabeharisoa and Callon 2003) could be reviewed.

In this article, supported by anthropologists who have been studying the involvement of patients and caregivers with science, we seek to understand how the intense arrival of ZV and CZVS scientists in the Metropolitan Region of Recife was seen, some of the reasons for micro families to accept their invitations and three recurring criticisms they formulated about these encounters. These images were varied and eloquent and, more importantly, from then on, relationships with scientists also diversified. In this intense construction of scientific ties, the families also communicated their analyses: what they imagined as "good science", as a "good scientist", and how it could "be good for both sides". When frustrated in these scientific meetings, some families began to avoid next invitations to participate in research projects, but this does not mean that they stopped attending offices of health specialists, offering up-to-date pharmaceuticals to alleviate their children's symptoms or, more recently, expecting the arrival of vaccines against covid-19 for this age group.

Faith in science remained, but not unconditionally. And, in such dark times experienced by science currently in Brazil, it is worth highlighting: criticizing is not the same as denying science. Like many of these families in Recife, we are also enthusiasts of science, but not of any science, nor carried out at any cost ${ }^{16}$. Informed by their experiences as mothers, caregivers, and companions of research subjects, these women were also doing science, feeding science with ZV and CZVS biomaterial and, above all, contributing with science that resulted from all the actors who had met in the city. Participating in science was, by no means, passive, but was expanding the scales of hope through which they could imagine the future of their children. Donating a little urine sample generated an immediate expectation as a concrete reward in the form of diapers or a food basket. Thus, it was possible to count on therapies and continued medical follow-up, based on the partnership between families and universities. Or even feed some hope, in a more altruistic or humanitarian act, based on a general meaning of help, that your daughter's blood could benefit many other children with the same health condition around the city and also in the future. An ethnography of these encounters and relationships with research aims, mainly, to affirm that science benefits greatly from being co-produced and maintaining itself as a public debate with and for all of us.
16 And not in line with what Sônia Maluf called a "re-emergence (...) of a reductionist view of the scientific field, which excludes perspectives that do not fit into a positivist and deterministic health format" (2021, 283, footnote 29). 


\section{References}

Barros, Alessandra S. S. 2021. "Deficiência, Síndrome Congênita do Zika e produção de conhecimento pela antropologia”. Revista Scientia 6 (1): 142-63.

Castro, Rosana. 2020. Economias políticas da doença e da saúde: uma etnografia da experimentação farmacêutica. São Paulo: Hucitec.

Diniz, Debora. 2016. Zika: do sertão nordestino à ameaça global. Rio de Janeiro: Civilização Brasileira.

Fleischer, Soraya. 2020a. "Circulação de esperança em tempos de Síndrome Congênita do Vírus Zika no Recife/PE”. In Desigualdades e Políticas da Ciência, org. Debora Allebrandt, Nádia Meinerz, e Pedro Nascimento, 325-62. Florianópolis: Casa Verde.

Fleischer, Soraya. 2020b. "Doutores”. In Micro: contribuições da Antropologia, org. Soraya Fleischer, e Flávia Lima, 77-88. Brasília: Athalaia.

Fleischer, Soraya, e Flávia Lima, orgs. 2020. Micro: contribuições da Antropologia. Brasília: Athalaia.

Latour, Bruno. 2000. Ciência em ação: como seguir cientistas e engenheiros sociedade afora. São Paulo: UNESP.

Lustosa, Raquel. "Mulheres". 2020. In Micro: contribuições da Antropologia, org. Soraya Fleischer, e Flávia Lima, 39-50. Brasília: Athalaia.

Maluf, Sônia. 2021. “Janelas sobre a cidade pandêmica: desigualdades, políticas e resistências". Tomo 38: 251-85.

Moreira, Tiago. 2014. "Understanding the role of patient organizations in health technology assessment". Health expectations: an international journal of public participation in health care and health policy 18 (6): 3349-57.

Moreira, Tiago, Orla O'donovan, e Etaoine Howlett. 2014. "Assembling dementia care: patient organisations and social research”. BioSocieties 9: 173-93.

Nunes, João Arriscado, e Ângela Marques Filipe, e Marisa Matias. 2010. "Os novos actores colectivos no campo da saúde: o papel das famílias nas associações de doentes". Alicerces: 119-28.

Pols, Jeannette. 2014. "Knowing patients: turning patient knowledge into science”. Science, Technology, \& Human Values 39 (1): 73-97.

Rabeharisoa, Vololona, Tiago Moreira, e Madeleine Akrich. 2014. "Evidence-based activism: Patients', users' and activists' groups in knowledge society". BioSocieties 9: 111-28.

Rabeharisoa, Vololona, Michel Callon, Angela Marques Filipe, João Arriscado Nunes, Florence Paterson, e Frédéric Vergnaud. 2012. "The dynamics of causes and conditions: the rareness of diseases in French and Portuguese patients' organizations' engagement in research". CSI Working Papers Series 026. Paris: Centre de Sociologie de l'Innovation (CSI), Mines ParisTech.

Rabeharisoa, Vololona, e Michel Callon. 2007. "The Growing Engagement of Emergent Concerned Groups in Political and Economic Life". Science Technology \& Human Values 33 (2): 230-61.

Rabeharisoa, Vololona, e Michel Callon. 2003. "Research 'in the wild' and the shaping of new social identities". Technology in Society 25: 193-204. 
Soraya Fleischer

Rabeharisoa, Vololona, e Michel Callon. 2002. "The involvement of patients' associations in research”. International Social Science Journal 54: 57-63.

Scott, Parry, Marion Quadros, Ana Claudia Rodrigues, Luciana Campelo Lira, Silvana Sobreira Matos, Fernanda Meira, e Jeíza Saraiva. 2017. "A epidemia de Zika e as articulações das mães num campo tensionado entre feminismo, deficiência e cuidados". Cadernos de Gênero e Diversidade 3 (2): 73-92.

Simas, Aissa. 2020. "Ciência, saúde e cuidado: um estudo antropológico sobre a pesquisa clínica no contexto da epidemia do Zika (Recife/PE)". Dissertação de mestrado, Universidade de Brasília, Brasília. 